\title{
EDITORIAL
}

\section{A new series on airway remodelling}

\author{
L-P. Boulet* and P.J. Sterk ${ }^{\#}$
}

I n today's respiratory research, airway remodelling is probably one the best examples of an area for which the level of excitement easily matches the level of confusion on its definition and implication. This seeming contradiction may, however, not be worrying at all in science. In fact, it is likely to be a powerful driving force of creative research, thereby generating and testing a variety of hypotheses.

Traditionally, tissue structure was considered to be relatively stable after an episode of embryonic development. However, it is becoming more and more evident that growth, turn-over and repair of tissue represent a continuous, lifelong process involving all resident cells and their extracellular matrix (ECM), both in health and disease. This is also very likely the case for intrapulmonary airways [1, 2]. At present, it is customary to reserve the term "airway remodelling" to conditions where the structure of the airways becomes "abnormal" as compared with that observed in healthy subjects.

Typical airway structural changes can be observed in chronic respiratory conditions such as asthma and chronic pulmonary obstructive disease $[2,3]$. Remodelling refers to a complex phenomenon involving changes in the number and/or type of resident cells and/or the quantity of various constituents of the ECM. Epithelial damage, vascular and glandular proliferation, increased smooth muscle mass, subepithelial fibrosis and increases in ECM constituents such as proteoglycans are among the best studied features of this complex phenomenon, although there is a need to better understand the time course of these processes. Airway remodelling may be observed at early stages of airway diseases before they become clinically evident $[4,5]$. It is usually considered secondary to an underlying inflammatory process through the action of various cytokines and mediators, although other mechanisms may be contributory $[1-3,6-8]$.

The interactions between resident cells and inflammatory cells involved in the development of remodelling are currently under investigation, and there is evidence that not only can inflammation influence remodelling but the opposite is also true, with these mutual interactions possibly contributing to the persistence of both processes [9, 10]. Although observed structural changes can contribute to the clinical features of

\footnotetext{
*Hôpital Laval, Institut de cardiologie et de pneumologie, I'Université Laval, Québec, QC, Canada \#Leiden University Medical Center, Leiden, The Netherlands.

STATEMENT OF INTEREST: A statement of interest for L-P. Boulet can be found at www.erj. ersjournals.com/misc/statements.shtml

CORRESPONDENCE: L-P. Boulet, Hôpital Laval, 2725, Chemin Sainte-Foy, Québec, QC, GIV 4G5 Canada. Fax: 1 4186564762. E-mail: Ipboulet@med.ulaval.ca
}

airway disease, including their severity and persistence, how these various modifications could lead to alterations in airway function and affect clinical outcome is still to be determined $[11,12]$.

Hence, there are many urgent research questions in this field. What are the basic mechanisms driving airway remodelling? Are these genetic, inflammatory or perhaps even mechanical? Can it be induced by environmental factors? What are the cytokines and growth factors involved? What in fact are the exact structural changes that we are talking about? How should tissue be sampled to measure those? Can this be done noninvasively, e.g. by imaging techniques? How does airway remodelling translate into changes of airway function? Is remodelling always detrimental, or can it be protective against airway narrowing? What is the eventual clinical expression of airway remodelling? Is it associated with particular clinical phenotypes? Furthermore, a key question is whether or not interventions should be directed against airway remodelling? Are our current interventions changing airway structure? And which are the novel approaches in this field?

This month, the European Respiratory Journal launches a series of review articles produced by global experts in the field, covering the above aspects of this topic. It will address the basic mechanisms and the main components of structural airway changes and how to assess these, the contribution of animal models to the understanding of abnormal repair processes and permanent changes of both lung and airway structure, and also the contribution of allergen exposure to airway remodelling in sensitised subjects. Finally, the clinical significance of airway remodelling, the influence of therapies on this and also the future research needs in this field will be discussed.

We are facing a new era in our understanding of airway disease, which has led to unconventional therapeutic options $[13,14]$. During the coming months, the European Respiratory Journal will present the science behind this, starting with FIXMAN et al. [15] reviewing the basic mechanisms of the development of airway structural changes.

\section{REFERENCES}

1 Bourbon J, Henrion-Caude A, Gaultier C. Molecular basis of lung development. In: Gibson GJ, Geddes DM, Costabel U, Sterk PJ, Corrin B, eds. Respiratory Medicine. London, Saunders/Elsevier Science Ltd, 2003; pp 65-81.

2 Bergeron C, Boulet LP. Structural changes in airway diseases: characteristics, mechanisms, consequences, and pharmacologic modulation. Chest 2006; 129: 1068-1087.

3 Postma DS, Timens W. Remodeling in asthma and chronic obstructive pulmonary disease. Proc Am Thorac Soc 2006; 3 : 434-439. 
4 Laitinen A, Karjalainen EM, Altraja A, Laitinen LA. Histopathologic features of early and progressive asthma. $J$ Allergy Clin Immunol 2000; 105: S509-S513.

5 Laprise C, Laviolette M, Boutet M, Boulet LP. Asymptomatic airway hyperresponsiveness: relationships with airway inflammation and remodelling. Eur Respir J 1999; 14: $63-73$.

6 Vignola AM, Chanez P, Bonsignore G, Godard P, Bousquet J. Structural consequences of airway inflammation in asthma. J Allergy Clin Immunol 2000; 105: S514-S517.

7 Tschumperlin DJ, Drazen JM. Mechanical stimuli to airway remodeling. Am J Respir Crit Care Med 2001; 164: S90-S94.

8 Holgate ST. Airway inflammation and remodeling in asthma: current concepts. Mol Biotechnol 2002; 22: 179-189.

9 Zhang S, Mohammed Q, Burbidge A, Morland CM, Roche WR. Cell cultures from bronchial subepithelial myofibroblasts enhance eosinophil survival in vitro. Eur Respir J 1996; 9: 1839-1846.
10 Davies DE, Wicks J, Powell RM, Puddicombe SM, Holgate ST. Airway remodelling in asthma: new insights. J Allergy Clin Immunol 2003; 111: 215-225.

11 James A. Airway remodeling in asthma. Curr Opin Pulm Med 2005; 11: 1-6.

12 Pascual RM, Peters SP. Airway remodeling contributes to the progressive loss of lung function in asthma: an overview. J Allergy Clin Immunol 2005; 116: 477-486.

13 Cox PG, Miller J, Mitzner W, Leff AR. Radiofrequency ablation of airway smooth muscle for sustained treatment of asthma: preliminary investigations. Eur Respir J 2004; 24: 659-663.

14 Stripp BR, Shapiro SD. Stem cells in lung disease, repair, and the potential for therapeutic interventions. State of the art and future challenges. Am J Respir Cell Mol Biol 2006; 34: 517-522.

15 Fixman ED, Stewart A, Martin JG. Basic mechanisms of development of airway structural changes in asthma. Eur Respir J 2007; 29: 379-389. 